\title{
Congress, the President, and the War Powers
}

\author{
William P. Rogers*
}

The issue before us is the constitutional authority of Congress and the President to commit forces to armed combat and questions related to such authority. These questions have been the subject of considerable debate and scholarly attention. ${ }^{1}$ Unfortunately, they are often approached polemically, with one side arguing the President's constitutional authority as Commander in Chief and the other asserting Congress' constitutional power to declare war; the implication often given is that these powers are somehow incompatible. On the contrary, the framers of the Constitution intended that there be a proper balance between the roles of the President and Congress in decisions to use force in the conduct of foreign policy.

In discussing these issues, I will first review the historical background of the war powers question, beginning with the Constitution itself and tracing the practice of the nation throughout our history. Then, placing the war powers issue in the modern context, I will discuss the issues which bear upon the exercise of presidential and congressional powers now and in the foreseeable future. Finally, from this perspective, I will describe what I believe the national interest requires in terms of a proper balance between the President and the Congress.

At the outset I would like to stress my behef that cooperation and consultation between the executive and legislative branches is the heart of the political process as conceived by the framers of the Constitution. In the absence of such cooperation, no legislation which seeks to define constitutional powers more rigidly can be effective. Conversely, given sucli cooperation, such legislation is unnecessary. The execu-

* Secretary of State, U.S. Department of State. A.B. 1934, Colgate University; LL.B. 1937, Cornell University.

1. See generally House COMm. on Foreign Affairs, 91St CONG., 2D Sess., Background INFormation on the Use of United States ARmed Forces in Foreion CoUNTRIES (Comm. Print 1970) [hereinafter cited as BaCKGROUNd INFormation 1970]; Senate Comm. on Foreign Relations, 91st Cong., 2D Sess., Documents Relatino to the War Power of Congress, the President's Authority as Commander in CFIEF, AND THE WAR IN INDOchINa (Comm. Print 1970) [hereinafter cited as DocuMents ON THE WAR PoWER 1970]; Hearings on Congress, the President, and the War Powers Before the Subcomm. on Natl Security Policy and Scientific Developments of the House Comm. on Foreign Affairs, 91st Cong., 2d Sess. (1970). 
tive branch fully respects Congress' right to exercise its constitutional role in decisions involving the use of military force and in the formulation of our nation's foreign policy. There is obvious need for, and great value in, congressional participation in such decisions. At the same time, lowever, there is a clear need in terins of national survival for preserving the constitutional power of the Prcsident to act in emergency situations.

\section{I}

\section{HISTORICAL BACKGROUND}

\section{A. Textual Authority and the Intention of the Framers}

Article I, section 8 of the Constitution grants Congress a number of specific powers relevant to our discussion, including the power "to . . . provide for the common Defence. . . ; To declare War . . . ; To raise and support Armies . . . ; To provide and maintain a Navy; To Inake Rules for the Government and Regulation of the land and naval Forces ...." The Senate, in particular, is given certam foreign relations powers to advise and consent to treaties and to the appointment of ambassadors and other officials. ${ }^{2}$ Congress has the power to make all laws which are necessary and proper for carrying out powers vested by the Constitution in the federal government. ${ }^{3}$ In addition, Congress has the sole authority to appropriate funds, ${ }^{4}$ a vital power in the war powers and foreign relations area.

The powers of the President that are relevant to this inquiry are found in article II. The President is vested with the executive power of the government, ${ }^{5}$ he is named Commander in Chief of the army and navy" and is required to "take Care that the Laws be faithfully executed." From these powers and the power to make treaties and to appoint and receive ambassadors is derived the President's constitutional authority to conduct the foreign relations of the United States.

The frainers of the Constitution were not writing in a historical or pohtical vacuum. Experience during the colomal period and under the Articles of Confederation had shown the need to strengthen the central government. The problem was to create a strong federal system and yet prevent tryanny. ${ }^{8}$ Accordingly, the framers established three powerful

2. U.S. CONST. art. II, $\S 2$ cl. 2 .

3. Id. art. I, $\$ 8 \mathrm{cl}$. 18 .

4. Id. art. I, $\S 7 \mathrm{cl} .2, \S 8 \mathrm{cls} .1,2,12, \S 9 \mathrm{cl} .7$.

5. Id. art. III, $\$ 1 \mathrm{cl} .1$.

6. Id. art. II, $\S 2 \mathrm{cl} .1$.

7. Id. art. II, $\$ 3$.

8. Solberg, Introduction to The Federal Convention and the Formation of THE UNION OF THE AMERICAN STates, at xc (W.U. Solberg ed. 1958). 
federal branches of government and depended upon the independence of each branch and their coequal powers to provide the checks and balances necessary to preserve the democracy.

The division of the war powers between the legislative and executive branches is typical of the constitutional concept of shared powers and checks and balances. By this division, the framers changed the prior federal procedure under the Articles of Confederation, in which the "sole and exclusive right and power of determining on peace and war" had been vested in the Legislature. ${ }^{\circ}$ They wished to take advantage of executive speed, efficiency, secrecy, and relative isolation from "public passions."10 At the same time, they wislied to avoid the dangers to desnocratic government exemplified by the unchecked British monarch who, as Hamilton noted, liad supreme authority not only to command the military and naval forces, but also to declare war and to raise and regulate fleets and armies. ${ }^{11}$ Mindful of the hardships which war can inpose on the citizens of a country and fearful of vesting too much power in any individual, the framers intended that decisions regarding the initiation of lostilities be made not by the President alone, nor by the House or Senate alone, but by the entire Congress and the President together. ${ }^{12}$ Yet it is also clear that the framers intended to leave the President certain indispensable emergency powers. ${ }^{13}$

The grant to Congress of the power to declare war was debated briefly at the Constitutional Convention and that well-known debate re-

9. ARTICles of CONFEDERATION OF 1781, art. IX. This consolidation of power in the Legislature was principally intended to put the war powers in the hands of the central government rather than the states, except in certain specified emergencies. A division of the war power between Congress and the President was not at issue, for the fear and dislike of monarchy was so great among the colonists that the Articles did not provide for an independent executive branch. Had the framers intended to give Congress exclusive control of the war powers they could have incorporated the same war powers provision into the Constitution.

10. See The Federalist No. 49, at 390-92 (J.C. Hamilton ed. 1864) (A. Hamilton); id. No. 63, at 476-77 (A. Hamilton). See generally id. Nos. 70-75 (A. Hamilton).

11. Id. No. 69, at 516 (A. Hamilton).

12. The Constitutional Convention rejected suggestions by various delegates to give the power to either branch alone. See $2 \mathrm{M}$. FarRand, THE Records OF THE Federal Convention of 1787, at 318-19 (1911). See also C.A. Berdahl, War Powers of the Executive in the United States 95 (IX U. Ill. Studies in the Social Sciences 1920):

The power of the President with regard to a declaration of war does not end with the functions of communication of information, and of recommendation. A declaration of war, like any other bill, order, resolution, or vote requiring the concurrence of both houses of Congress, must be submitted to the President for his approval or disapproval.

13. 2 M. FARRAND, supra note 12 , at $318-19$. That the scope of these emergency powers was controversial from the beginning is evidenced by Hamilton's vigorous attack on President Jefferson's conservative interpretation of his defensive powers in his conduct of the limited war with the Barbary Pirates in 1801. See note 23 infra. 
veals the essential intention of the framers. The Committee of Detail submitted to the general convention a draft article which gave the Congress the power "to make war." Pursuant to a motion by Madison and Gerry, this was amended to the power "to declare war."14 This change in wording was not intended to detract from Congress' role in decisions to engage the country in war. Rather it was, in my opinion, a recognition of the need to preserve in the President an emergency power, as Madison explained it, "to repel sudden attacks"15 and also to avoid the confusion of "making" war with "conducting" war which is the prerogative of the President. ${ }^{16}$

The necessity to repel sudden attacks was the case cited by the framers in which the President clearly had power to act immediately on his own authority. In 1787, this was the one situation in which it was evident that emergency action was required. But the rationale behind the concept is broader-that is, in emergency situations, the President has the power and responsibility to use the armed forces to protect the nation's security. ${ }^{17}$ This conclusion is borne out by subsequent practice $^{18}$ and judicial precedents. ${ }^{19}$ In fact, however, much of the debate at the time of the convention centered on curbing the European inonarch's

14. 2 M. FARRAND, supra note 12 , at 318-19.

15. Id. at 318.

16. Id. at $318-19$.

17. For example, the President's power to repel sudden attacks undoubtedly includes the power to provide against the imminent threat of attack. This concept was recognized early in connection with Congress' constitutional power to call forth the militia to repel invasions. In Martin v. Mott, 25 U.S. (12 Wheat.) 19 (1827), Mr. Justice Story found constitutional the Act of Feb. 28, 1795, ch. 36, 1 Stat. 424, which empowered the President to call forth the militia if the country were invaded or in imminent danger thereof:

[T]he power to provide for repelling invasions includes the power to provide against the atteinpt and danger of invasion, as the necessary and proper means to effectuate the object. One of the best means to repel invasions is to provide the requisite force for action, before the invader himself has reached the soil.

Id. at 28. See also Durand v. Hollins, 8 F. Cas. 111 (No. 4186) (C.C.S.D.N.Y. 1860), which recognized the Executive's emergency power and duty to respond quickly to threats against the lives and property of Annerican citizens abroad. The origin of the notion set forth in Durand, that citizens have a right to protection abroad, is unclear. It is listed as an unquestionable privilege of federal citizenship in the Slaughter-House Cases, 83 U.S. (16 Wall.) 36, 79 (1873), with no authority given; it is also mentioned with approval in In re Neagle, 135 U.S. 1, 64 (1889). See also 22 U.S.C. $\$ 1731$ (1964) (granting to naturalized citizens in foreign countries the same United States Government protection accorded native-born citizens); 22 U.S.C. $\$ 1732$ (1964) (requiring the President to use such means as are necessary, short of war, to effect the release of Anerican citizens unjustly imprisoned in foreign countries). For authority that the decision whether to extend protection in a given case is a matter within the Executive's discretion, see E.M. Borchard, The Diplomatic Protection of CitIZENS ABROAd 29-30, 363-65 (1928).

18. See notes $23-48$ infra and accompanying text.

19. See notes 55-67 infra and accompanying text. 
tradition of precipitating offensive wars ${ }^{20}$ and transferring to the federal government the war powers previously exercised by the states. Little attention was given to the scope of the President's power to use the armed forces for defensive purposes to protect the nation or its security imterests. $^{21}$

The constitutional division of authority in the war powers area parallels the constitutional balance between the Executive and Legislature in other fields. By dividing these powers between the two branches, the Constitution established a system that, except in emergency situations, functions most effectively when decisions to involve the nation in armed conflict are arrived at jointly by the President and Congress.

\section{B. Selected Historical Examples}

In addition to the textual authority and the framers' intentions, it is necessary to consider the practical exercise of the war powers of Congress and the President since the Constitution was adopted. Many scholars have reviewed the historical records, ${ }^{22}$ and I do not think it would be useful to repeat their efforts. I believe it is important, however, to identify the trend that has developed.

From the earliest years of the republic we find examples of presidential use of the armed forces without congressional approval. At first, these were very limited in cliaracter. For example, in 1801 President Jefferson sent on his own authority a squadron of ships to protect American vessels from the Barbary pirates; however, he authorized them only to take defensive actions. ${ }^{23}$ The scope of presidential initiative expanded

20. See The Federalist No. 4, at 65-70 (J.C. Hamilton ed. 1864) (J. Jay).

21. R. Russell, The United States Congress and the Power to Use Military Force Abroad, Apr. 15, 1967, at 25-63 (unpublished thesis in Fletcher School of Law and Diplomacy Library).

22. See generally BaCKGRoUnd Information 1970, supra note 1; C.A. BERDAHL, supra note 12; House COMM. ON FOREIGN AFFAIRS, BACRGROUND INFORMATION ON THE Use of UNITEd States ARMed Forces in Foreign Countries, H.R. Rep. No. 127, 82d Cong., 1st Sess. (1951); R. Lzopold, The Growth of AMErican Foreign Policy (1962); J.G. Rogers, WorLd POLICING AND THE CONSTITUTION (1945); R. Russell, supra note 21, at 64-389; Moore, The National Executive and the Use of the Armed Forces Abroad, 21 NAv. WAR CoL. Rzv. 28 (Jan. 1969); Note, Congress, the President, and the Power to Commit Forces to Combat, 81 HARv. L. Rev. 1771 (1968).

23. BACKGROUND INFORMATTON 1970, supra note 1, at 40; J.G. ROGERS, supta note 22, at 46-47. In his first annual message to Congress on December 8, 1801, President Jefferson explained his aetions:

Unauthorized by the Constitution, without the sanction of Congress, to go beyond the line of defence, the vessel, being disabled from committing further hostilities, was liberated with its crew. The Legislature will doubtless consider whether, by authorizing measures of offence also, they will place our force on an equal footing with that of its adversaries. I communicate all material information on this subject, that, in the exercise of this important function 
during the 19th and early 20th centuries. President Polk sent American forces into the disputed territory near the Rio Grande in January 1846, where they engaged in battle with the Mexicans purely on presidential authority. ${ }^{24}$ In 1900 President McKinley sent 5,000 troops to China, without congressional authorization, to protect Americans and help put down the Boxer Rebellion. ${ }^{25}$ President Theodore Roosevelt, on his own authority, dispatched gunboats to the Canal Zone area. ${ }^{28}$ Also, Presidents T. Roosevelt, Taft, Wilson, and Coolidge intervened and temporarily occupied other Latin American and Caribbean countries without prior congressional approval. ${ }^{27}$ Nicaragua, for example, was occupied and, in effect, administered by U.S. marines for nearly seven years, from 1926-1933, without authorization by Congress. ${ }^{28}$

Thus, history prior to World War II shows an increasing exercise by the President of his constitutional powers to use American armed

confided by the Constitution to the Legislature exclusively, their judgment may form itself on a knowledge and consideration of every circumstance of weight.

11 ANNals of Cong. 11, 12 (1801). President Jefferson's conservative interpretation of his war powers, even against a declared adversary, was vigorously attacked by Hamilton. In his view, once the nation is attacked or war is declared by a foreign nation, the President is authorized to respond with whatever force he thinks necessary:

[I] $t$ is the peculiar and exclusive province of Congress, when the nation is at peace to change that state into a state of war; whether from calculations of policy, or form provocations, or injuries received: in other words, it belongs to Congress only, to go to War. But when a foreign nation declares, or openly and avowedly inakes war upon the United States, they are then by the very fact already at war, and any declaration on the part of Congress is nugatory; it is at least unnecessary.

7 THE WORKS OF AlEXANDER HAMILTON 746-47 (J.C. Hamilton ed. 1851) (emphasis in original); for a diseussion of the war with Tripoli that gave rise to this attack by Hamilton on Jefferson's legal theory, see Wormuth, The Vietnam War: The President Versus the Constitution, in 2 The Vietnam War and International LaW 711, 723-25 (R.A. Falk ed. 1969). Hamilton's view received judicial approval in The Brig Amy Warwick, 67 U.S. (2 Black) 635, 665-71 (1863) (The Prize Cases) [see note 57 infra and accompanying text].

24. BACKGROUND INFORMATION 1970, supra note 1, at 39; J.G. Rogers, supra note 22, at 48-49; Wormuth, supra note 23, at 726. Although the Mexican War subsequently became a declared war [Act of May 13, 1846, ch. 16, 9 Stat. 9], there was some initial congressional opposition. See 15 Cong. GLoBe, 29th Cong., 1st Sess. 782-88 (1846). This opposition had so increased two years later that the House passed a rider to a resolution honoring General Taylor for his actions "in a war unnecessarily and unconstitutionally begun by the President of the United States." See 17 Cong. Globe, 30th Cong., 1st Sess. 95, 343-44 (1848).

25. J.G. ROGERS, supra note 22, at 58-62. BACKGROUND INFORMATION 1970, supra note 1, at 40, puts the size of the American force at 2,500.

26. BaCKGround Information 1970, supra note 1, at 41 ; S.F. Bemis, A DiploMatic History of THE UNITED States 513-15 (4th ed. 1955); J.G. Rogers, supra note 22 , at 73-74.

27. S.F. BEMIS, supra note 26, at 519-38; J.G. ROGERS, supra note 22 , at $74-78$; Wormuth, supra note 23 , at 748-49.

28. BACKGROUND INFORMATION 1970 , at 43 ; J.G. Rogers, supra note 22 , at $77-78$. 
forces abroad, without first obtaining congressional sanction. The fact that there was relatively little congressional opposition to presidential actions during this period ${ }^{20}$ may have been due to several possible factors. First, the Presidents were acting in the context of a nationally popular consensus that the United States should assume a posture consistent with its emerging power, particularly in the Western Hemisphere.$^{30}$ Second, a large majority of the 19th and early 20th-century presidential actions occurred in the Caribbean, where this country's power was so predominant that there was little or no chance of forcible response to our actions. Therefore, the risks which article I, section 8 was designed to reduce never arose. In short, there being no risk of major war, one could argue there was no violation of Congress' power to declare war. ${ }^{31}$

It has been suggested that even President Franklin Roosevelt's 1940-41 executive agreements with Britain effecting an exchange of destroyers for bases in the Western Atlantic and with Denmark and Iceland for bases in Greenland and Iceland can be considered a legitimate exercise of presidential power in hemispheric defense. ${ }^{32}$ However, the factor distinguishing these agreements from prior presidential actions in the Western Hemisphere was the then unmistakably great risk that the United States would become involved in a major war.

I cite these historical precedents not because I believe they are dispositive of the constitutional issues-far from it-but to illustrate how the constitutional system adapts itself to historical circumstances. Whatever the reasons for presidential initiatives during this period, they seem to have been responsive to the times and to have reflected the mood of the nation.

The history of the exercise of war powers by the President and the Congress since World War II further exemplifies the process of expanding presidential power. In 1950, at the invitation of the Government of the Republic of Korea and pursuant to resolutions of the United Nations Security Council ${ }^{33}$ President Truman committed air, naval, and land forces numbering over a quarter of a million to a war im Korea

29. See BACKGROUnd INFORMATION 1970, at 39-44. But see note 24 supra.

30. See Reveley, Presidential War Making: Constitutional Prerogative or Usurpation?, 55 VA. L. REV. 1243, 1260-61 (1969).

31. Note, supra note 22 , at 1790.

32. Statement of Henry Steele Commager, Hearings on S. 731 Before the Senate Comm. on Foreign Relations, 92d Cong., 1st Sess. (Mar. 8, 1971) [3 C.F.R. - (1971)]. The statement is based on the assumption that the President's emergency powers can, under certain circumstances, encompass hemispheric defense as a necessary correlative of his power to defend the United States.

33. S.C. Res. 1499, 5 U.N. SCOR, 473d meeting 7-18 (1950); S.C. Res. 1508 Rev. 1, 5 U.N. SCOR, 474th meeting 4, 16-17 (1950). 
without congressional authorization. The Truman administration based its authority to commit these troops squarely on the President's constitutional power. It asserted that "[t]he President, as Commander in Chief of the Armed Forces of the United States, has full control over the use thereof." ${ }^{\prime 3}$ Citing past instances of presidential use of armed force in the broad interests of American foreign policy, the administration asserted that there was a "traditional power of the President to use the Armed Forces of the United States without consulting Congress," and also placed reliance on the fact that the action was taken under the United Nations Charter, a part of both the treaty and international law which the President is constitutionally empowered to execute. $^{36}$

President Eisenhower souglit congressional authorization for possible engagement of American forces in the Middle East and in the area around Formosa. In his request for a resolution on Formosa ${ }^{37}$ he stated the view that:

Authority for some of the actions which might be required would be inherent in the authority of the Commander in Chief. Until Congress can act I would not hesitate, so far as my constitutional powers extend, to take whatever emergency action might be forced upon us in order to protect the rights and security of the United States.

However, a suitable congressional resolution would clearly and publicly establish the authority of the President as Commander in Chief to employ the Armed Forces of this Nation promptly and effectively for the purposes imdicated if in his judgment it became necessary. ${ }^{38}$

When President Eisenhower sent 14,000 troops into Lebanon in 1958 he did so without seeking specific congressional approval and without specifically basing his authority on the 1957 Middle East Resolution. ${ }^{30}$ He stated:

The inission of these forces is to protect American lives-there are about 2,500 Americans in Lebanon-and by their presence there to assist the Government of Lebanon to preserve its territorial integrity and political imdependence. . . .
. . . I have, however, come to the sober and clear conclusion

34. U.S. Dep't of State, Authority of the President to Repel the Attack in Korea, 23 Dep't State Bull. 173 (1950).

35. Id. at 174 .

36. Sen. Comms. on foreign Relations \& Armed Services, 82D Cong., 1st Sess., Powers of the President to Send ARMed Forces OUtside the United States 2-3, 20-22 (Comm. Print. 1951).

37. Act of January 29, 1955, Pub. L. No. 84-4, ch. 4, 69 Stat. 7.

38. 101 CONG. REC. 601 (1955).

39. 22 U.S.C. $\$ 1962$ (1964) [Act of March 9, 1957, Pub. L. No. 85-7, 71 Stat. 5]. 
that the action taken was essential to the welfare of the United States. It was required to support the principles of justice and international law upon which peace and a stable international order depend. ${ }^{40}$

In October 1962 President Kennedy ordered the quarantine of Cuba:

acting under and by virtue of the authority conferred upon nie by the Constitution and statutes of the United States, in accordance with the aforementioned resolutions of the United States Congress and the Organ of Consultation of the American Republics, and to defend the security of the Umited States. . . . 41

The resolution of Congress referred to by the President was the Cuban Resolution $^{42}$ which, unlike the other area resolutions, ${ }^{43}$ contained no grant of authority to the President; it simply declared that the United States was determined to use any means necessary to prevent Cuba from extending its subversive activities through the hemisphere and from creating or using an externally supported military capacity which would endanger United States security.

In April 1965, President Johnson sent United States Marines into the Dominican Republic without congressional authorization, stating initially that he was exercising the President's power to protect the safety of American citizens. ${ }^{44}$ A few days later, when the peace-keeping objectives of the action became predominant, he explained his action as an exercise of the President's power to preserve the security of the hemisphere in accordance with the principles enunciated in the OAS Charter. ${ }^{45}$ At no time during the Dominican action did the President seek congressional authorization.

When President Johnson began sending American combat troops to South Viet-Nam in 1965, he relied on a combination of his own constitutional authority as Chief Executive and Commander im Chief, ${ }^{40}$ the Southeast Asia Collective Defense Treaty ${ }^{47}$ and the Tonkin Gulf Resolu-

40. 104 Cong. ReC. 13,903-04 (1958).

41. Pres. Proc. No. 3504, 27 Fed. Reg. 10,401 (1962). The resolution of Congress referred to was the Cuban Resolution, which was passed by the House and Senate one month before the Cuban missile crisis and the quarantine proclamation. For the text of the resolution of the Organ of Consultation of the American Republics issued on October 23, 1962, see [1962] O.A.S. SEC'y GEN. ANN. REP. 3-5 (OEA/Ser. D/III.14).

42. Act of October 3, 1962, Pub. L. No. 87-733, 76 Stat. 697.

43. See notes 37,39 supra.

44. See N.Y. Times, Apr. 29, 1965, at 1, col. 8; id., Apr. 30, 1965, at 1, col. 8.

45. See Statement by the President, May 2, 1965 in N.Y. Times, May 3, 1965, at 10 , col. 1. The Council of the OAS subsequently authorized a multination peacekeeping force by its resolution of Nov. 5, 1962. [1962] O.A.S. SEC'Y GEN. ANN. REP. 5.

46. U.S. Dep't of State, The Legality of United States Participation in the Defense of Viet-Nam, 54 DeP'T STATE BULL. 474, 484-85 (1966).

47. Southeast Asia Collective Defense Treaty, with protocol (SEATO), entered 
tion. 48

Thus, over the last 20 years, one can see that Presidents have given varying rationales for executive action and varying interpretations of the necessity of congressional authorization. I think there are two points which are underscored by this period in our history. First, the area resolutions $^{49}$ were some evidence of congressional approval; in general, however, they arose in an atmosphere of crisis or in a factual context different from that in which they were eventually relied upon. The question is not whether these resolutions are useful to Presidents-of course they are-but instead whether such open-ended authorizations are a valid and effective means for Congress to exercise its constitutional power.

Second, it serves no useful purpose to argue today whether, or to what extent, past presidential decisions regarding the use of military force have served the national interest. The very concept of what best serves the national interest has undergone significant change since the uses of force of the 1950's and 1960's. This administration recognizes that protection of our national interest does not require an automatic United States military response to every threat. In my opinion, this new recognition, known as the Nixon Doctrine, ${ }^{50}$ will be a significant aid to achieving better balanced executive-legislative participation in decisions regarding the use of military force.

\section{Judicial Precedents}

There are relatively few judicial decisions concerning the relationship between the Congress and the President in the exercise of their respective war powers under the Constitution. The courts have usually

into force for U.S. Feb. 19, 1955, [1955] 6 U.S.T. 81, T.I.A.S. No. 3170, 209 U.N.T.S. 28.

48. U.S. Dep't of State, supra note 46, at 485. The Tonkin Gulf Resolution [Act of Aug. 10, 1964, Pub. L. No. 88-408, 78 Stat. 384, repealed by Act of Jan. 12, 1971, Pub. L. No. 91-672, \$12] provided that "the Congress approves and supports the determination of the President, as Commander in Chief, to take all necessary measures to repel any armed attack against the forces of the Umited States and to prevent further aggression" [id. \$1] and that "the United States is ... prepared, as the President determines, to take all necessary steps including the use of armed force." ld. $\$ 2$.

49. See notes $37,39,42,48$ supra.

50. The ain of the Nixon Doctrine is to increase the participation of other nations in individual and collective defense efforts. While reaffirming our treaty commitments and offering a shield against threats from nuclear powers aimed at our alhes or other nations vital to our security, we now look to the nation directly threatened to assume the primary responsibility for providing the manpower necessary for its defense. Richard M. Nixon, United States Foreign Policy for the 1970'sBuilding for PeAce 10-21 (Report of the President to Congress, Feb. 25, 1971). 
regarded the subject as a political question ${ }^{51}$ and refused jurisdiction. For example, in Luftig v. McNamara, ${ }^{52}$ the Court of Appeals for the District of Columbia Circuit upheld the dismissal of a suit by an Army private to enjoin the Secretary of Defense from sending him to Viet-Nam on the ground that the war was unconstitutional. The court stated:

It is difficult to think of an area less suited for judicial action than that into which Appellant would have us intrude. The fundamental division of authority and power established by the Constitution precludes judges from overseeing the conduct of foreign policy or the use and disposition of military power; these matters are plainly the exclusive province of Congress and the Executive. ${ }^{53}$

Accordingly, to the extent issues regarding the war powers are resolved, their resolution is more likely to come, as has been the case in the past, ${ }^{54}$ through political interaction of the President, Congress, and the electorate. In the fimal analysis, that is the most appropriate means for the settlement of fundamental constitutional questions of this character.

There are, however, a few court decisions which suggest some rough guidelines relevant to the war powers issue. First, the decisions indicate that courts recognize and accept the President's authority to employ the armed forces in hostilities without express congressional authorization. For example, in Durand v. Hollins, ${ }^{55}$ the Second Circuit held in 1860 that, in the absence of congressional authorization, the Executive had broad discretion in determining when to use military

51. Massachusetts v. Laird, 400 U.S. 886 (1970); Mora v. McNamara, 387 F.2d 862 (D.C. Cir.), cert. denied, 389 U.S. 934 (1967); Luftig v. McNamara, 373 F.2d 664 (D.C. Cir.), cert. denied, 387 U.S. 945 (1967). A political question has been defined as a question which the Constitution requires to be determined by an agency of government other than the judiciary. See generally Brief for Defendant at 35-41, Massachusetts v. Laird, supra; A. Bickel, The Least Dangerous Branch (1962); H. Wechsler, Toward Neutral Principles of Constitutional Law, in Principles, PoliTICS AND FUNDAMENTal Law 3-48 (1961); Scharpf, Judicial Review and the Political Question: A Functional Analysis, 75 YaLe L.J. 517 (1966); Tigar, Judicial Power, The "Political Question Doctrine," and Foreign Relations, 17 U.C.L.A.L. REv. 1135 (1970).

52. 373 F.2d 664 (D.C. Cir.), cert. denied, 387 U.S. 945 (1967).

53. 373 F.2d at $665-66$.

54. Although there has historically been a certain amount of congressional opposition to executive exercise of the war power, to my knowledge there has never been a major conflict in the war powers area between legislation and presidential action. In my view this is the result of compromise and political interaction between the executive and legislative branches and is real proof of the successful operation of our political system.

55. 8 F. Cas. 111 (No. 4186) (C.C.S.D.N.Y. 1860). This case involvcd a suit for damages against a Navy Commander who, on orders of the President and Secretary of the Navy, bombarded and burned the city of Greytown, Nicaragua, in retaliation against a revolutionary government that refused to make reparation for damage done there to U.S. citizens and their property. Mr. Justice Nelson (on assignment to the second circuit) decided in favor of the defendant; the case never reached the Supreme Court. Cf. Perrin v. United States, 4 Ct. Cl. 543 (1868). 
force abroad in order to respond quickly to threats against American citizens and their property. ${ }^{56}$ In the Prize Cases, ${ }^{57}$ during the Civil War, the Supreme Court upheld President Lincoln's southern blockade despite the absence of a declaration of war or other specific congressional authorization. The Court said that when war is initiated by the other party, the President is not only authorized, but obliged to resist force by force ${ }^{58}$ and has broad discretion in deciding what measures are demanded by the crisis. ${ }^{59}$ The decision was also based on the Court's finding of a general congressional sanction of the war from ancillary legislation and subsequent congressional ratification..$^{60}$

Youngstown Sheet \& Tube Co. v. Sawyer, ${ }^{61}$ the Steel Seizure Case, in which the Supreme Court invalidated President Truman's seizure of United States steel mills during the Korean War, is sometimes cited as indicating the limits of the President's independent constitutional authority. However, it is important to note that the issue in that case was not the President's authority to conduct hostilities, but the scope of his power over a clearly domestic matter, labor-management relations. Moreover, the Court noted, and several Justices based their concurring opinions $^{62}$ on the fact, that Congress had enacted a number of laws concerning domestic labor disputes and in so doimg exphicitly withheld the power of seizure from the President.

Viewmg the Steel Seizure Case as involving a clash between Congress and the President over a domestic matter leads to a second conclusion. There would appear to be limits on the nature of legislation that Congress can pass bearimg on foreign affairs, especially the actual conduct of war. This was foreseen in the concurring opinion of four Justices in Ex parte Milligan: ${ }^{\circ 3}$

Congress has the power not only to raise and support and

56. 8 F. Cas. 111, 112 (No. 4186) (C.C.S.D.N.Y. 1860).

57. 67 U.S. (2 Black) 635 (1863). These cases involved suits by four shipowners alleging that their ships had been illegally seized as prizes under President Lincoln's blockade against the Confederacy. The Court held the blockade legal. Id. at 671 . Mr. Justice Nelson and three others dissented, arguing that the President had no authority to impose a blockade and seize the property of U.S. citizens without a congressional declaration of war. $I d$. at 698-99.

58. Id. at 668 .

59. Id. at 670 .

60. Id. at $670-71$.

61. 343 U.S. 579 (1952).

62. Concurring opinions of Mr. Justice Frankfurter, id. at 604-09; Mr. Justice Burton, id. at 655-60; Mr. Justice Clark, id. at 662-65.

63. 71 U.S. (4 Wall.) 2 (1866). The case arose as a habeas corpus proceeding contesting the legality of a conviction by a inilitary tribunal of a Northern civilian in Indiana during the Civil War. The Court invalidated the conviction, holding that the military tribunal had no jurisdiction, since neither the Congress nor the President could constitutionally authorize the trial of a civihian before a military tribunal in a state that lad been loyal to the Union during the Civil War. Id. at 118-22. 
govern armies but to declare war. It has, therefore, the power to provide by law for carrying on war. This power necessarily extends to all legislation essential to the prosecution of war with vigor and success, except such as interferes with the command of the forces and the conduct of campaigns. That power and duty belong to the President as commander-in-chief. ${ }^{64}$

In fact, direct conflict between legislation and presidential action in the field of foreign affairs has rarely, if ever, occurred ${ }^{\text {eb }}$ and there are few judicial pronouncements on what would happen in the event of a clear collision in the area of the war powers. Perhaps Mr. Justice Jackson stated the wisest rule when he said that in the event of a collision, “. . . any actual test of power is likely to depend on the imperatives of events and contemporary imponderables rather than on abstract theories of law." "Bo

A third guideline that emerges is that when acts of Congress authorize presidential action, the President's power is at its zenith; it encompasses both the authority delegated to him by Congress and whatever independent constitutional authority he may have with respect to the subject matter. This situation is exemplified by the much-quoted case of United States v. Curtiss-Wright Export Corp. ${ }^{67}$ There the Supreme Court held that restrictions upon congressional delegation of power to the Pres-

64. Id. at 139 .

65. Cf. E.S. Corwin, The President 259 (4th rev. ed. 1957): "Actually Congress has never adopted any legislation that would seriously cramp the style of a President attempting to break the resistance of an enemy or seeking to assure the safety of the national forces."

66. Youngstown Sheet \& Tube Co. v. Sawyer, 343 U.S. 579, 637 (1952) (Jackson, J., concurring). In an early case involving seizure of vessels on the high seas it was held that the President could not act inconsistently with a specific legislative prohibition. Little v. Barreme (The Flying Fish), 6 U.S. (2 Cranch) 170 (1804), which involved the seizure, in accordance with presidential orders interpreting the Act of Feb. 9, 1799, ch. 2, 1 Stat. 613, of a ship sailimg from a French port. The Act only authorized seizure of ships bound to French ports. Chief Justice Marshall, for a unanimous Court, held the seizure unlawful, but noted in passing that the presidential order might well. have been lawful in the absence of congressional authorization were it not for the express negation of authority contained in the Act. Id. at 176. See also Youngstown Sheet \& Tube Co. v. Sawyer, supra at 660-61 (Clark, J., concurring).

The Flying Fish involved an issue squarely within the specific grant of authority to Congress "to ... make Rules concerning Captures on Land and Water" [U.S. CoNST. art I, $\S 8 \mathrm{cl}$. 11], and for this reason should not be considered authority for congressional predominance in an area of shared powers, such as the war powers. Moreover, The Flying Fish was decided before the political-question doctrine was formulated by Chief Justice Marshall in Foster v. Neilson, 27 U.S. (2 Pet.) 253, 306 (1829), and, therefore, although it has never been overruled, a similar case would probably never reach decision on the merits today.

67. 299 U.S. 304 (1936). See also Martin v. Mott, 25 U.S. (12 Wheat.) 19 (1827), mvolving the Act of Feb. 28, 1795, ch. 36, 1 Stat. 424, which delegated authority to the President to call forth the militia in the event of an invasion or the imminent threat theręof. 
ident in domestic affairs do not apply with respect to delegation in external affairs, because of the President's extensive independent authority in that realm and the desirability of allowing him inaximuin flexibility in exercising that authority. ${ }^{68}$ There are numerous other examples of wide definition of presidential powers when acting under and in accordance with an act of Congress. ${ }^{69}$

II

\section{The Modern Context}

Turning from an examination of history to an analysis of the modern context in which the President and Congress operate, I am impressed by the fundamental changes in the factual setting in which the war powers must be exercised. Indeed, it is this very change in setting which has raised difficult constitutional issues that cannot be answered by reference to history alone.

The primary factors underlying this transformation are evident and need only be summarized. They include, first, the energence of the United States as a world power. Since World War III we have inaintained a large, standing military capacity sufficiently well-equipped and mobile to enable the United States to play a major peacekeeping role almost anywhere in the world and with little delay. This development has generated a reliance upon the United States by other nations-which has been translated into a series of defense treaties-and a sense of re-

68. 299 U.S. at 319-22. The Curtiss-Wright case is more often cited for the Court's dicta than its holding. The Court saw the foreign-affairs powers as inherent attributes of national sovereignty and, consequently, vested exclusively in the federal government, to be exercised by the President as "the sole organ of the nation in its external relations." Id. at 319, quoting from a speech by Marshall, 10 ANNALs of Cong. 613 (1800) (miscited by the Court to volume 6). The Court suggested that this "very delicate, plenary and exclusive power of the President" with respect to foreign relations did not depend upon congressional authorization, although, like every other governmental power, it had to be exercised in subordination to the applicable provisions of the Constitution. Id. at 320 . For the most recent chapter of the Curtiss-Wright debate see New York Times Co. v. United States, 91 S. Ct. 2140 (1971).

The case holding has been interpreted as withdrawing "virtually all constitutional limitation upon the scope of congressional delegation of power to the President to act in the area of international relations." Jones, The President, Congress and Foreign Relations, 29 CALIF. L. REv. 565, 575 (1941). But cf. recent Supreme Court decisions which contain warnings (dicta) that the Curtiss-Wright holding may not be followed should a similar set of facts arise in the future: Afroyim v. Rusk, 387 U.S. 253, 267 (1967) (Congress cannot provide for loss of citizenship for voting in a foreign election); Zemel v. Rusk, 381 U.S. 1, 17 (1965) (Congress cannot provide for trial by courts-martial of civilians employed by or accompanying United States armed forces outside the United States); Reid v. Covert, 354 U.S. 1, 39-41 (1957) (Congress cannot provide for trial by courts-martial of citizens who are civilian dependents accompanying the armed forces outside the United States).

69. See Youngstown Sheet \& Tube Co. v. Sawyer, 343 U.S. 579, 635 n.2 (1952) (concurring opmion), and cases cited therem. 
sponsibility on the part of this country to fulfill our commitments in good faith. ${ }^{70}$

A second factor that characterizes the modern context is the development of technology, especially in the ficld of nuclear weaponry. The fear of nuclear war and the importance of deterrence have engendered a sense of need to be able to take prompt, decisive Executive action. On the other hand, the danger that even a minor skirmish could lead to a confrontation of the major powers and raise the spectre of nuclear war, emphasizes the desirability of appropriate congressional participation in decisions which risk mvolving the United States in hostilities.

Third, the institutional capacities of the Presidency have facilitated the broad use of presidential powers. The heightened pace, complexity, and hazards of contemporary events often require rapid and clear decisions. The nation nust be able to act flexibly and, in certain cases, without prior publicity. These institutional advantages of the Presidency, which are especially important in the area of foreign affairs, were pointed out in The Federalist: the unity of office, its capacity for secrecy and dispatch, and its superior sources of information. ${ }^{71}$

Unlike the Presidency, the institutional characteristics of Congress have not lent themselves as well to the requirements of speed and secrecy in times of recurrent crises and rapid change. Its numerous menibers and their diverse constituencies, the complexity of its decisionmaking processes, and its constitutional tasks of debate, discussion, and authorization inevitably make Congress a more deliberative, public, and diffuse body. ${ }^{72}$

To balance this picture, it is also necessary to recognize the inherent limitations of the Presidency. There are few significant matters which can be accomplished by presidential order alone. The essence of presidential power is the ability to enlist public support for national policy, ${ }^{73}$ and in this the President needs the cooperation of Congress. Vir-

70. This Administration has begun to reverse the trend of expanding U.S. military involvement abroad. The Nixon Doctrine [see note 50 supra] means that while the United States must continue to honor its commitments and to play a large and active role in world affairs, we should not seek in all cases to have the preponderant role. We seek a new partnership with nations of the world in which they become increasingly self-reliant and assume greater responsibilities for their own welfare and security and that of the international community. See, e.g., U.S. DEP'T OF STATE, United States Foreign Policy 1969-1970, at II \& 36-39 (Report of the Secretary of State, Mar. 26, 1971).

71. See, e.g., The Federalist No. 64, at 485-86 (J. Hamilton ed. 1864) (J. Jay); id. No. 74, at 552 (A. Hamilton).

72. Reveley, supra note 30 , at 1271.

73. See R.E. Neustadt, Presmential Power 10 (1960):

The President of the United States has an extraordimary range of formal powers, of authority in statute law and in the Constitution. Here is testimony that despite his "powers" he does not obtain results by giving orders- 
tually every presidential program requires implementing legislation and funding. Through their powers of investigation and supervision, congressional committees have amply demonstrated their ability to inspire national debate, focus public opinion, and thereby influence presidential policy. The Senate's power to advise and consent to treaties and appointments serves as a constant reminder of the Senate's indispensable role in foreign policy.

Of course, the electorate is the ultimate restraint upon the President and Congress in the exercise of the war powers. As President Nixon said in his "State of the World" message: "Our experience in the 1960's has underlined the fact that we should not do more abroad than domestic opinion can sustam." The President and Congress inust be sensitive to the people's willingness to suffer the potential physical, econormic, and political costs of military actions. The nation's ability to sustain long-term military action depends on the ability of the President and Congress to convince the people of the wisdom of their policies.

\section{III}

\section{The Proper Balance Between Congress and the Presment}

Thus far I have discussed what has happened to the war powers over the course of our history and described the modern context in which those powers must be exercised. The most difficult question is still before us. What slould be the proper balance between the Congress and the President in the future?

We must start from the recognition that the exercise of the war powers under the Constitution is essentially a political process. It requires cooperation and mutual trust between the President and Congress, as well as the wise judgment of both, if the nation's interests are to be well served.

Recently, the Senate Committee on Foreign Relations lias had before it several bills ${ }^{75}$ that attempt to define in advance and codify the war powers of the President and the Congress. In my opinion, the longterm interests of the United States will not be served by such legislation. I believe the sponsors of these bills and the adininistration share the saine objectives; both want to avoid involving the nation in wars, but if we

or not, at any rate, merely by giving orders. He also has extraordinary status, ex officio, according to the customs of our government and politics. Here is testimony that despite his status he does not get action without argument. Presidential power is the power to persuade.

74. RICHARD M. NIXON, supra note 50, at 16.

75. See, e.g., SJ. Res. 18, 92d Cong., 1st Sess. (introduced by Sen. Taft, Jan. 27, 1971); S. 731, 92d Cong., 1st Sess. (imtroduced by Sen. Javits, Feb. 10, 1971); S.J. Res. 59, 92d Cong., 1st Sess. (mtroduced by Sen. Eagleton, Mar. 1, 1971); S.J. Res. 95, 92d Cong., 1st Sess. (introduced by Sen. Stennis, May 11, 1971). 
are forced into hostilities, all recognize that United States involvement must be quickly and effectively undertaken in full accordance with constitutional processes. Thus, the difference of opinion is not in objectives, but how best to achieve those objectives.

I am opposed to the pending legislation as a way to achieve these objectives because (1) it attempts to fix rigidly and to freeze the allocation of the war powers between the President and Congress-a step which the framers in their wisdom quite deliberately decided against ${ }^{70}-$ and (2) it attempts in a nuniber of respects to narrow the power given the President by the Constitution. ${ }^{77}$

Regarding the first point, these bills reflect an approach that is not consistent with our constitutional tradition. The framers of the Constitution invested the executive and legislative branclies with war powers appropriate to their respective roles and capabilities, without attempting in advance to specify their precise roles in every setting of time and circumstance. This specification was left to the political processes, which is characteristic of the constitutional systen of separation of powers. Our constitutional system is founded on an assumption of cooperation rather than conflict, and this is vitally necessary in matters of war and peace. The effective operation of the system requires that both branclies work together from a common perspective rather than seeking to forge shackles based on the assumption of divergent perspectives.

As for the second aspect, although the bills recognize to a significant extent the President's full range of constitutional authority, they do tend to limit the President in some questionable ways. It appears, for example, that two of the bills ${ }^{78}$ do not cover situations like that of the 1962 Cuban missile crisis. In failing to recognize the need for immediate action and the propriety of a presidential response to such situations, the bills are unduly restrictive. It is inconceivable that the President could have carried out the delicate diplomatic negotiations which led to

76. See notes 9-21 supra and accompanying text.

77. See notes 5-7 supra and accompanymg text.

78. S. 731, 92d Cong., 1st Sess. \& 1 (1971) would only authorize the President to use the armed forces, in the absence of a declaration of war, in four specific situations: (1) to repel a sudden attack against the U.S., its territories, and possessions; (2) to repel an attack against U.S. armed forces on the high seas or lawfully stationed abroad; (3) to protect the lives and property of U.S. nationals abroad; and (4) to comply with a "national commitment" as defined in S. Res. 85, 91st Cong., 1st Sess., 115 CoNo. REC. 2604 (1969) (one that "exclusively results from affirmative action taken by the executive and legislative branches ... through means of a treaty, convention, or other legislative instrumentality specifically intended to give effect to such a commitment." S.J. Res. 59, 92d Cong., 1st Sess. $\$ 3$ (1971) would limit unauthorized presidential military action to (1) repelling an attack on the U.S.; (2) repelling an attack on U.S. armed forces; and (3) withdrawing U.S. citizens from countries where their lives are subjected to an imminent threat. 
the removal of the missles from Cuba had there been a full-scale congressional debate prior to his deciding on a course of military and diplomatic action.

The bills would also restrict the President's authority to deploy forces abroad short of hostilities. This raises a serious constitutional issue of interference with the President's authority as Commander in Chief. Moreover, requiring prior congressional authorization for deployment of forces can deprive the President of a valuable instrument of diplomacy that is most often used to calm rather than enflame a crisis. For example, such a restriction could seriously hamper the President's ability to make a demonstration of force backing up the exercise of our rights and the fulfillment of our responsibilities in Berlin or in the Mediterranean in connection with the Middle East situation.

At least two of the bills would require that action initiated by the President within his specified authority be terminated after 30 days unless Congress enacts sustaining legislation, ${ }^{79}$ and three of the bills would permit Congress to terminate presidential action in less than 30 days. ${ }^{80}$ The bills would provide for expedited action on such legislation, but would not and could not ensure defmitive congressional action within the 30-day period. This raises another constitutional issue: Can the President's authority under the Constitution, for example, to protect the nation against sudden attack, be limited or terminated by congressional action or inaction? Also, the 30-day limitation may cause practical problems; once our forces are committed to hostilities, it might prove impossible to terminate those hostilites and provide for the safety of our forces within an arbitrary time period. To the extent the legislation would impinge in these ways upon the President's authority as Coinmander in Chief and Chief Executive, it is of doubtful constitutionality. ${ }^{81}$

Certainly, another consideration must be the effect of such legislation upon potential enemies. To circumscribe-or even appear to weaken-presidential ability to act in emergency situations would run the grave risk that an enemy might miscalculate the ability of the United States to act in a crisis. This might embolden another nation to provoke a crisis or take other actions which undermine international peace and security.

We do not have sufficient foresight to provide wisely for all contingencies that may arise in the future. I am sure the founding fathers acted on that premise, and we should be most reluctant to reverse

79. S. 731, 92d Cong., 1st Sess. $\$ 1$ 1C. (1971); S.J. Res. 95, 92d Cong., 1st Sess. $\S 4$ (b) (1971).

80. S. 731, 92d Cong., 1st Sess. \$ 1D. (1971); S.J. Res. 59, 92d Cong., 1st Sess. $\S 4$ (1971); S.J. Res. 95, 92d Cong., 1st Sess. \$ 4(a) (1971).

81. See note 64 supra and accompanying text. 
their judgment. Moreover, it is clear that Congress' ability to exercise its constitutional powers does not depend on restricting in advance the necessary flexibility which the Constitution has given the President.

At the same time, I would emphasize that my use of the terin "flexibility" should not be interpreted as a euphemism for unchecked Executive power. Soine have argued that Congress' power to declare war should be interpreted as a purely symbolic act with little real substance in a world in which declared wars have become infrequent despite the existence of real lostilities. ${ }^{82}$ In my judgment it would be improper to do so. Congress' power to declare war retains real meaning in the modern world context. While the legislative form in which the power is exercised may change, nevertheless the constitutional imperative remains: if the nation is to be taken into war or to embark on actions which run serious risk of war, the critical decisions must be made only after the most searching examination and on the basis of a national consensus, and they must be truly representative of the will of the people. For this reason, we must ensure that such decisions reflect the effective exercise by the Congress and the President of their respective constitutional responsibilities.

\section{CONCLUSION}

What needs to be done to ensure that the constitutional framework of shared responsibility for the exercise of the war powers works in the nation's best interests?

First, we should explore ways of reinforcing Congress' information capability on issues involving war and peace. For exanple, the State Department's assistant secretaries in charge of each geographic region could provide the Senate Committee on Foreign Relations with full and regular briefings on developments in their respective regions. Reg. ular and continuing briefings would enable the Committee to keep abreast of developing crisis situations. This would be in addition to the

82. Formal declarations of war are often deliberately avoided because they tend to indicate both at home and abroad a commitment to total victory and may impede settlement possibihities. The issuance of a formal declaration can also have cortain legal results: certain treaties may be cancelled or suspended; trading, contracts, and debts with the enemy may be suspended; vast emergency powers become operative domestically; and the legal relations between neutral states aud belligerents can be altered. See generally Eagleton, The Form and Function of the Declaration of War, 33 AM. J. INT'L L. 19 (1938). On the other hand, Professor Moore argues that "probably the most compelling reason for not using a formal declaration . . . is that there is no reason to do so. As former Secretary of Defense McNamara has pointed out '[T]here has not been a formal declaration of war-anywhere in the world-since World War II." Moore, supra note 22, at 33. See generally J.F. MAURICE, HostiLITIES Without Declaration OF WAR (1883). 
numerous official and informal contacts which regularly take place between the members of the two branches.

Second, Congress and the President must consult in earnest, since it is not only Congress that is weakened by a lack of consultation. Our nation's foreign policy itself is weakened when it does not reflect continuing interaction and effective consultation between the two branches.

Third, Congress should effectively exercise the war powers which it already has under the Constitution. In its 1969 Report on the National Commitments Resolution, ${ }^{83}$ the Senate Committee on Foreign Relations recognized that neither constitutional amendment nor legislative enactment is required for Congress to assert its constitutional authority. "If Congress makes clear that it intends to exercise [the war] powers, it is most unlikely that the executive will fail to respect that intention." $\mathrm{I}$ agree with that conclusion.

Fourth, there is the need to act speedily, and sometimes without prior publicity, in crisis situations. We should try to find better institutional methods to keep these requirements from becoming an obstacle to Congress' exercising its full and proper role. Suggestions have come from a number of quarters for the establishment of a jomt congressional committee which could act as a consultative body with the President in times of emergencies. ${ }^{85}$

Fifth, we must preserve the President's ability to act in emergencies in accordance with his constitutional responsibilities. By its very nature, this ability cannot be defined precisely in advance. Let me emphasize that I am not suggesting a presidential carte blanche. As I indicated at the beginning of my discussion, I believe the framers of the Constitution intended decisions regarding the initiation of hostilities to be made jointly by the Congress and the President, except in emergency situations. I beheve that constitutional design remains valid today.

In conclusion, I would emphasize my belief that the war powers question requires thorough consideration and study so that it is fully understood by the Legislature, the Executive and the electorate. This is a basic question affecting our constitutional structure and the security of our nation. It is most important that such a matter be considered deliberately and calmly, in an atmospluere free from the emotion and the passions that have been generated by the Viet-Nam conflict.

The constitutional framework of shared war powers is wise and serves the interests of the nation well in the modern world. The recog-

83. S. Rep. No. 129, 91 st Cong., 1st Sess. (1969) (to accompany S. Res. 85, 91st Cong., 1st Sess. (1969) on National Commitments).

84. Id. at 32 .

85. See, e.g., H.R. 7290, 92d Cong., 1st Sess. (introduced by Rep. Horton, Apr. 6, 1971). 
[Vol. 59:1194

nition of the necessity for cooperation between the President and Congress in this area and for the participation of both in decisionmaking could not be clearer than it is today. What is required is the judicious and constructive exercise by each branch of its constitutional powers rather than seeking to draw arbitrary lines between them. 